\title{
Editorial
}

\section{Special Issue on Catholic Youth \& Young Adult Ministry}

\author{
Arthur D. Canales
}

Citation: Canales, Arthur D. 2021. Special Issue on Catholic Youth \& Young Adult Ministry. Religions 12: 403. https://doi.org/10.3390/ rel12060403

Received: 11 March 2021

Accepted: 23 April 2021

Published: 31 May 2021

Publisher's Note: MDPI stays neutral with regard to jurisdictional claims in published maps and institutional affiliations.

Copyright: (C) 2021 by the author. Licensee MDPI, Basel, Switzerland. This article is an open access article distributed under the terms and conditions of the Creative Commons Attribution (CC BY) license (https:/ / creativecommons.org/licenses/by/ $4.0 /)$.
Department of Theology, Marian University, Indianapolis, IN 46222, USA; acanales@marian.edu

It gives me great pleasure to announce and provide the readership of Religions this special issue on Catholic youth and young adult ministry. The ensemble of authors who contributed to this journal are some of the world's most active and renowned scholars, theologians, and practitioners within the academic and pastoral field of Catholic youth and young adult ministry.

The impetus of this special issue is the watershed event announced by Pope Francis, on 13 January 2017, calling for a worldwide General Assembly of the Synod of Bishops to be held in Rome in October of 2018. From the outset, Pope Francis declared that this synod would focus on young people, ages 16-29. The pope declared, "I want you [young people] to be the center of attention because you are in my heart". As a result of the 2018 synod on young people, the very first papal Apostolic Exhortation (book)—promulgated on 25 March 2019, and titled Christus Vivit! (Christ is Alive!)—came to fruition. It is the first time a sitting pope has written a specific document on young people. Such a historic and bold move by Pope Francis laid the groundwork for national Catholic churches (individual countries, e.g., United States, Brazil, Australia, Poland, etc.) to address youth and young adult ministry, and eventually to write their own documents on young people. It is because of Pope Francis' initiative that this special issue on Catholic youth and young adult ministry is so relevant and current.

The timely nature of this special issue serves to amplify voices in the field of Catholic youth and young adult ministry. This journal will be an important contribution to Catholic youth and young adult ministry literature on both pastoral and academic levels for years to come. Moreover, this journal will be used in Catholic courses on youth or young adult ministry as required reading for years to come. The articles provide insight, theology, and pastoral practice for those who educate and train current and future youth and young adult ministers and those who work in the trenches of youth and young adult ministry. This special issue will be of specific interest to pastors, teachers, youth ministers, campus ministers, young adult ministers, specialized ministers of adolescents and teenagers, conformation coordinators, middle school youth workers, and diocesan directors of youth and young adult ministry.

I want to offer a brief synopsis of the articles in the order in which they appear in the journal. I have selected the international renowned theologian Rossano Sala's contribution to be the leadoff article, entitled "Youth Ministry after the Synod on Young People-Ten Points of No Return". Professor Sala offers the following insights regarding the whole synodal journey and in particular Christus Vivit by Pope Francis: (a) presencethe lives of the young are a theological place in which God makes himself present; (b) frailty - weakness and failure in youth need to be accompanied by closeness, tenderness, gentleness, and consolation; (c) searching-we discover young people to be open and available; (d) discernment-recognizing, interpreting, and choosing together will enable communities to follow the Spirit; (e) proclamation-young people have a right to hear Jesus Christ announced; (f) spirituality — quality spiritual experiences will help young people to enjoy personal friendship with the Lord; (g) family - a welcoming church becomes a home for all young people; (h) voluntary work-charitable commitment opens young people to meaningful relationships and the exchange of gifts; (i) vocation-each one is personally loved and called by God by name; and (j) synodality-being and walking together in the 
Church are conditions for sharing the mission. These ten points give us a first overview for thinking about and carrying out ministry with youth and young adults.

The second article, by assistant professor of ministry, Jodi Hunt, is an intriguing piece titled "And Then There Was Zoom: A Catholic Theological Examination on the Development of Digital Youth Ministry". In her article, she examines the phenomenon and the new world of digital youth ministry in light of Covid-19. She maintains that digital youth ministry is here to stay and we should approach ministry in a viral or digital setting in the same manner that "brick and mortar" spaces approach ministry with young people. Hunt explains the virtues of digital youth ministry practice and addresses digital accompaniment and understanding the digital youth audience. She stresses that the importance of being Christ-like communicators is key for doing digital youth ministry. As Hunt concludes her article, she discusses the importance of reaching young people who are disaffiliated with the Catholic Church and who live on the margins. How does digital youth ministry in a Covid world connect with marginalized youth: LGBTQ youth, the financially poor, and/or those in rural areas? In the final analysis, digital youth ministry provides youth, as well as the youth minister, with a unique opportunity to communicate the Catholic faith, the teaching of Christ, and the spiritual life of the Church in new and fresh ways that prior generations did not have to consider or imagine.

The third article, by assistant professor of religious education Tracey Lamont, addresses "Ministry with Young Adults: Toward a New Ecclesiological Imagination". Lamont maintains that many young adults (18-34 years of age) feel that the church is an unwelcoming place, have no sense of belonging, are anxious about finding meaningful employment, struggle with racial injustices, and experience a pervasive sense of loneliness. For Lamont, there seems to be a tremendous disconnect between the daily experience of young adulthood and the Catholic Church in the United States ministry practice with young adults. Lamont recommends a new ecclesiological imagination that enhances the conceptions of the New Evangelization by Popes John Paul II, Benedict XVI, and Francis. She claims that although people use Pope Francis' new language of "missionary discipleship" for evangelization, most parish and diocesan programs for young adults in the United States have not fully embraced or utilized his visionary direction. Lamont argues that authentic ecclesiological imagination requires an openness to dialogue by inviting ministry leaders to form meaningful relationships with young adults. This required attuning one's self to God's presence in our midst and in each encounter we have, and to accompanying young people on their spiritual journeys. Missionary discipleship is not a new program - it is a whole new way of being for the church. Only time will tell if Pope Francis' vision of missionary discipleship will come to fruition in ministry with young adults or will be just another buzzword that fizzles out and does not engage the lives of contemporary young adults.

The fourth article is by Paul Jarzembowski, Director of the Office of Youth, Young Adult, and Family Life for the United States Conference of Catholic Bishops. He provides a marvelous ministry model in "Mobilizing the Field Hospital: Pastoral Care as a Paradigm for Ministry with Young Adults". Jarzembowski begins his article by suggesting there is a "tipping point" that young adults (ages 18-39) have reached as a result of Covid-19, job losses, and low pay wages. Jarzembowski suggests that a new model is needed to address young adults that responds to their lived realities rather than our preconceived assumptions, and argues against the "usual programs" of ministry for young adults. Jarzembowski centers his model on a phrase borrowed from Pope Francis: "the field hospital", which is a revival of the historic Christian approach of intentionally engaging in pastoral care and ministry, and particularly with young adults. It is also a method for doing dynamic accompaniment with young adults. The field hospital motif is brilliant because it covers a multitude of young adult pastoral concerns, from student loan debt and family expectations to loneliness and suicide. The field hospital model helps to connect young adults with their Catholic communities, while simultaneously addressing their needs and empowering them to become more spiritual through these turbulent times of 
living in debt, job uncertainty, living in a digital world, and a myriad of other concerns. For Jarzembowski, the field hospital model is one that is ripe for Catholic young adults, and it resonates strongly with the biblical parable of the Good Samaritan found in the Gospel of Luke.

The fifth article is by associate professor Theresa A. O'Keefe and doctoral candidate Emily Jendzejec, who team-up to write "A New Lens for Seeing: A Suggestion for Analyzing Religious Belief and Belonging among Emerging Adults through a ConstructiveDevelopmental Lens". The authors suggest an interpretive lens, based on the constructivedevelopmental theory of Robert Kegan, to analyze qualitative interviews of emerging adults (ages 18-26). The article begins with a brief survey of the major modalities for studying religious belief, belonging, and disaffiliation among emerging adults. O'Keefe and Jendzejec critique these modes for missing important elements of religious belief and belonging, which they argue would be important to ministers and religious leadership. They demonstrate how a constructive-developmental lens would help researchers recognize, first, the research subject's cognitive capacity to make meaning and, second, how religious belief and belonging factors into the subject's meaning making. Such analysis would, in turn, result in more usable research findings, that could help ministers and religious leaders build appropriate interventions for emerging adults.

The sixth article is another tag-team essay by Maureen K. Day, assistant professor of religion and society, and Barbara H. McCrabb, Associate Director of the Secretariat of Catholic Higher Education and Campus Ministry for the United States Conference of Catholic Bishops, who write "Integrating Ministerial Visions: Lessons from Campus Ministry". The article addresses Catholic campus ministry in higher education and particularly the shift in ministry focus between the professionally trained, advanced degreed ministers as distinct from lay "missionaries" who participate in a 5-6 weeks training program that prepares them for peer ministry. Day and McCrabb argue that both professional ministers and missionaries do provide opportunities for college-age students to grow. The missionaries tended to concentrate their activities on Bible studies, evangelization, reconciliation and various women's and men's groups on campus. The professional ministers gravitated toward works of charity, social justice initiatives, and interfaith/interreligious activities. Both professional ministers and missionaries found common ground when it came to the Sunday Eucharist, retreats, small faith-sharing groups, discipleship programs, leadership development, immersion trips, and social activities. The USCCB established a task force to foster dialogue and discussion between the professional ministers and the missionaries. The outcome was to create a "layered approach" to campus ministry, a vision that creates a shared vision and unity. Hopefully, the collaboration with the professional ministers and missionaries will yield a fruitful appreciation for mutual respect for each group's giftedness.

The seventh article is by Chris Miller, a religious studies instructor, who writes an essay titled "The Sexual Abuse Crisis in the U.S.: Its Effects on Catholic Youth Ministry, and a way Forward Through Relational Ministry Utilizing the Developmental Relationships Framework". This article provides a brief history of the sexual abuse of minors in the Catholic Church in the United States, the Church's valiant attempt to make it safer for teenagers, and the impact of the sexual abuse crisis on Catholic youth ministry. Miller advocates for the use of Search Institute's "Developmental Relational Framework", a framework that offers Catholic youth ministers five areas to help young people thrive into adulthood in an effort to have "protection and prevention meet practical and pastoral" in ministry to young people. In the final analysis, building relationships is still the gold standard in Catholic youth ministry, and competent youth ministers will have to find creative ways to keep ministering safely and wisely during these turbulent times.

The eighth article is by Charlotte McCorquodale, President of Ministry Training Source, whose essay is titled "New Directions in Youth and Young Adult Ministry Leadership: Where Have We Been and More Importantly Where Are We Headed"? She provides a brief history of some of the major trends in Catholic youth and young adult ministry, which 
she likens to a pendulum swinging back and forth. She lists several pendulum swings: (a) CYO to comprehensive youth ministry, (b) varying catechetical methodologies, (c) toward the New Evangelization, (d) from program-focused to discipleship and accompaniment, (e) the Coronavirus pandemic, and (f) the youth synod and Christus Vivit. These shifts in ministry give a different direction to youth and young adult ministry. With the advent of Pope Francis' Christus Vivit, there have been renewed opportunities for ministry directions with young people. McCorquodale highlights themes from Christus Vivit that professionals from the field identified as pathways to accompaniment with youth and young adults. Moreover, she discusses the new skill set that is required by current and future youth and young adult ministers, including a new savviness for accompaniment skills. The Catholic Church is moving in a new direction because of Pope Francis' Christus Vivit, a direction that has been met with affirmation and fanfare thus far by Catholic practitioners.

The ninth and final article of this special edition on Catholic youth and young adult ministry is by yours truly. I have chosen to write about a topic that has been in the back of my mind for over a decade now: the way Catholic parishes in the United States do confirmation catechesis. This might be the only article not influenced by Christus Vivit or Covid-19 in this special issue, but it is a very important topic for Catholic youth ministry and confirmation literature and charts new territory. At any rate, my article is titled "Models and Methods for Confirmation Catechesis in Catholic Youth Ministry". The essay gives a brief history of the origins and early church development of confirmation and then moves into the two models for confirmation: (a) the liturgical model and (b) the religious education model. Next, the article examines the typical approach that parishes utilize for confirmation catechesis, which is either a one-year or two-year model that follows the school calendar. The "meat" of the article is in the last few sections, that deal with methods of confirmation, and I propose three methods, but have two others also in mind. The article ends with a section entitled "Strengths and Limitations of the Three Methodologies", which offers insights and critiques of the three models addressed. This is a pragmatic essay for those who work directly with confirmation or coordinate confirmation catechesis in the parish or diocese.

Editing this journal has been a year-long labor of love. I have had the privilege to work with some of the finest Catholic youth and young adult ministry scholars and practitioners in the country and abroad. Even though 2020 was a year that brought many hardships as a result of Covid-19, it was a year that allowed youth and young adult to be creative and to flourish in ways that had not been tried before. The young Church and the Catholic ministry owe Pope Francis, his writing Christus Vivit, and the ingenuity of Catholic youth and young adult ministers in the trenches a debt of gratitude.

My sincere hope and prayer is that this journal will be used for many years to come in college, graduate, and seminary courses on youth and/or young adult ministry. Moreover, that the contributions here help to expand the growing field of Catholic youth and young adult ministry as an academic study for those in the profession of youth and/or young adult ministry education.

Funding: This research received no external funding.

Conflicts of Interest: The author declares no conflict of interest. 